\title{
ANALISIS FAKTOR- FAKTOR YANG MEMPENGARUHI KONDISI FINANCIAL DISTRESS PADA PERUSAHAAN YANG DELISTING DARI JAKARTA ISLAMIC INDEX TAHUN 2012-2016
}

\author{
Ikhwani Ratna \& Marwati \\ Dosen Fakultas Ekonomi dan Ilmu Sosial UIN SUSKA RIAU \\ Email :weni2783@gmail.com
}

\begin{abstract}
ABSTRAK
Penelitian ini bertujuan untuk menguji faktor yang dapat mempengaruhi kondisi financial distress. Faktor yang di uji dalam penelitian adalah Leverage, Operatimg Capacity dan Profit Margin. Penelitian ini menggunakan alat pengujian regresi logistik, mengambil objek perusahaan-perusahaan yang Delisting dari Jakarta Islamic Index yang berjumlah 28 perusahaan dari tahun 2012-2016. Data yang digunakan dalam penelitian ini adalah data sekunder yang diperoleh dari laporan keuangan yang diterbitkan perusahaan. Sampel ditentukan dengan Metode Purporsive Sampling yaitu berdasarkan kriteria yang ditetapkan dan diperoleh sebanyak 8 perusahaan yang mana penelitian dilakukan selama 5 tahun sehingga didapatkan 40 sampel yang terdiri dari 15 perusahaan yang mengalami financial distress dan 25 perusahaan yang non distress. Untuk mendapatkan jumlah perusahaan yang termasuk kategori financial distress dan non distress tersebut, penelitian ini menggunakan analisis diskriminan model Abbas. Hasil analisis data dengan menggunakan regresi logistik menyatakan bahwa variabel yang berpengaruh signifikan terhadap financial distress adalah variabel operating capacity yang diproksikan dengan total asset turn over yang memiliki pengaruh signifikan dengan tingkat signifikansi $<5 \%$. Sedangkan leverage dan profit margin tidak berpengaruh signifikan terhadap financial distress.
\end{abstract}

Kata kunci : Financial Distress, Leverage, Operating Capacity, Profit Margin, Regresi Logistic

\section{ABSTRACT}

This research aims to test several factors influencing financial distress condition. The factors tested in this research are Leverage, Operating Capacity and Profit Margin. This research used logistic regression test tool to take 28 object companies that filed Delisting from Jakarta Islamic Index from 2012 to 2016. Data used in this research is secondary data obtained from financial statements published by the companies. The samples were determined by Purposive Sampling method, based on criteria defined. Eight companies were obtained on which the research was conducted for 5 years, resulting in 40 samples consisting of 15 companies experiencing financial distress and 25 non distress companies. To obtain the company samples for financial distress and non-distress categories, this research used Abbas-model discriminant analysis. The results of data analysis by logistic regression method suggested that the only variable that had significant effect on financial distress was proxied operating capacity, with total asset turn over having significant effects with level of significance of < $5 \%$. While leverage and profit did not have significant effect on financial distress.

Keywords : Financial Distress, Leverage, Operating Capacity, Profit Margin, Logistic Regression 


\section{PENDAHULUAN}

Setiap negara pasti ingin selalu meningkatkan perekonomian agar terus mencapai kemajuan dan kesejahteraan. Seperti halnya Indonesia, negara-negara berkembang lainnya selalu berusaha untuk terus memperbaiki dan mengembangkan sektor ekonomi hingga dapat menjadi negara maju. Untuk mencapai hal tersebut pemerintah melakukan pembangunan dan pengendalian secara menyeluruh terhadap sektor-sektor dan sistem yang saling bersinergi. Di Indonesia, perekonomian tumbuh dan berkembang dengan berbagai macam kegiatan usaha dan lembaga-lembaga yang ada. Perkembangan yang terjadi meliputi munculnya instrumen syariah dipasar modal sejak tahun 1997. Diawali dengan lahirnya reksadana syariah yang diprakarsai oleh dana reksa. Selanjutnya, disusun indeks yang secara khusus terdiri dari komponen saham-saham syariah yaitu Jakarta Islamic Indeks (JII).

Perusahaan merupakan suatu badan yang didirikan oleh perorangan atau lembaga dengan tujuan utama untuk memaksimalkan kekayaan pemegang saham. Pada dasarnya, tujuan didirikannya suatu perusahaan adalah untuk memaksimumkan keuntungan perusahaan dan kemakmuran pemilik perusahaan. Maka dari itu pihak manjemen harus dapat menghasilkan keuntungan yang optimal dan pengendalian yang seksama terhadap kegiatan operasional, terutama yang berkaitan dengan keuntungan perusahaan.

Disamping itu ada pula tujuan lain yang tidak kalah penting yaitu dapat terus bertahan (survive) dalam persaingan, berkembang (growth) serta dapat melaksanakan fungsi-fungsi sosial lainnya dimasyarakat. Dengan tujuan tersebut pihak manajemen perusahaan dituntut untuk melakukan kinerja secara optimal dalam aktivitas perusahaan, terutama masalah keuangan sehingga terhindar dari kondisi rugi dan bangkrut.

Kebangkrutan perusahaan biasanya diawali dengan kondisi kesulitan keuangan (financial distress). Kondisi financial distress mempunyai arti bahwa perusahaan mengalami kondisi keuangan pada setiap tahunnya semakin menurun. Kondisi ini pada umumnya ditandai dengan berbagai kondisi. Salah satunya ialah perusahaan selama dua tahun berturut-turut mempunyai laba bersih negatif (Mas'ud dan Srengga, 2012).

Kondisi financial distress ini terjadi sebelum adanya kebangkrutan serta memicu kondisi keuangan perusahaan akan semakin memburuk. Apabila keadaan perusahaan yang sudah mendekati financial distress biasanya manajemen perusahaan mengambil keputusan untuk menutup semua kegiatan dalam perusahaan baik itu kegiatan produksi maupun kegiatan operasional lainnya sebelum terjadinya kebangkrutan atau yang sering disebut dengan likuidasi. Kesulitan keuangan dapat disebabkan oleh ketidakmampuan perusahaan dalam mengantisipasi perkembangan global yang akan mengakibatkan pengecilan volume usaha sehingga pada akhirnya mengakibatkan kebangkrutan perusahaan. Kesulitan keuangan suatu perusahaan dapat tercermin dari keuangan perusahaan saat mengalami tahap penurunan kondisi keuangan perusahaan yang terjadi sebelum

mengalami kebangkrutan. Jika tidak diselesaikan dengan benar, kesulitan kecil tersebut bisa berkembang menjadi kesulitan yang lebih besar dan bisa sampai pada kebangkrutan.

Banyak perusahaan yang baru berjalan beberapa tahun namun tiba-tiba gulung tikar akibat bangkrut. Tidak jarang pula perusahaan besar tanpa diduga mengalami pailit. Bahkan 
perusahaan mapan dan sudah berusia tua pun tak luput dari ancaman kebangkrutan. Salah satu perusahaan yang sudah tergolong cukup lama beroperasi kemudian mengalami kebangkrutan adalah Kodak. Kodak merupakan pemain utama dalam dunia film, kamera dan industri percetakan selama lebih dari 125 tahun. Manajemen yang buruk serta kurangnya inovasi membuat mereka kalah saing. Sehingga pada tahun 2012, Kodak terpaksa mengajukan permohonan perlindungan kebangkrutan meski pada akhirnya dapat kembali pulih setelah membayar utang sebanyak USD 3,4 M (Sindo News.com).

Perusahaan yang mengalami financial distress merupakan perusahaan yang tidak memenuhi kriteria untuk listing di Jakarta Islamic Index. beberapa perusahaan yang delisting dari Jakarta Islamic Index karena financial distress disajikan pada tabel 1. dibawah ini:

Tabel 1. Daftar Perusahaan yang Mengalami Financial Distress

\begin{tabular}{clccccc}
\hline Kode & Nama Perusahaan & $\mathbf{2 0 1 2}$ & $\mathbf{2 0 1 3}$ & $\mathbf{2 0 1 4}$ & $\mathbf{2 0 1 5}$ & $\mathbf{2 0 1 6}$ \\
\hline ANTM & $\begin{array}{l}\text { Aneka Tambang } \\
\text { (Persero) Tbk. }\end{array}$ & $2,993,116$ & 421,032 & $-775,286$ & $-701,439$ & 64,806 \\
\hline EXCL & XL Axiata Tbk. & $2,764,647$ & $1,032,817$ & $-891,063$ & $-25,338$ & 375,516 \\
& & & & & & \\
\hline INDY & Indika Energi Tbk. & 843,296 & $-660,103$ & $-379,285$ & $-1,126,347$ & $-104,231$ \\
& & & & & & \\
\hline KRAS & Krakatau Steel Tbk. & $-189,145$ & $-166,872$ & $-1,951,109$ & $-4,785,716$ & $-180,724$
\end{tabular}

\section{Sumber: www. Idx.co. id}

Fenomena diatas menunjukkan bahwa kondisi kesulitan keuangan belum teratasi sehingga kebangkrutan sangat mungkin terjadi. Financial distress terjadi sebelum kebangkrutan. Untuk meminimalisir resiko kebangkrutan, perusahaan perlu melakukan analisis prediksi kebangkrutan untuk memprediksi ada atau tidaknya potensi kebangkrutan perusahaan serta menganalisis faktor-faktor yang berpengaruh terhadap kondisi financial distress. Kemampuan dalam memprediksi kebangkrutan akan memberikan keuntungan banyak pihak, terutama kreditur dan investor.

Penelitian ini merujuk pada penelitian yang dilakukan oleh Hanifah (2013) sehingga sebagian variabel yang digunakan dalam penelitian ini adalah sama. Hanifah (2013) melakukan penelitian terhadap perusahaan manufaktur yang terdaftar di Bursa Efek Indonesia selama 2009-2011.
Perbedaan penelitian ini dengan penelitian yang dilakukan oleh Hanifah (2013) adalah pengurangan variabel yaitu Good Corporate Governance, Current Ratio, dan Return on asset, serta menambah variabel dengan Profit Margin yang mengacu pada penelitian Novandri (2014). Penelitian ini juga memiliki perbedaan dengan penelitian sebelumnya yaitu dalam penentuan sampel perusahaan yang mengalami financial distress, penelitian Hanifah (2013) menggunakan Interest Coverage Ratio sedangkan dalam penelitian ini akan menggunakan analis is diskriminan oleh Abbas (2011).

\section{Rumusan Masalah}

Berdasarkan latar belakang yang diuraikan diatas, maka rumusan masalah dalam penelitian ini adalah:

1. Apakah Leverage berpengaruh terhadap kondisi financial distress perusahaan yang delisting dari Jakarta Islamic index. 
2. Apakah Operating Capacity berpengaruh terhadap kondisi financial distress perusahaan yang delisting dari Jakarta Islamic index.

3. Apakah Profit Margin berpengaruh terhadap kondisi financial distress perusahaan yang delisting dari Jakarta Islamic index.

\section{TINJAUAN PUSTAKA \\ Teory Agency}

Teori keagenan (Agency theory) menggambarkan hubungan antara dua individu yang berbeda kepentingan yaitu prinsipal dan agen. Jensen dan Meckling (1976) menyatakan bahwa teori keagenan merupakan teori ketidaksamaan kepentingan antara pihak yang memberi wewenang (prinsipal) yaitu investor dengan pihak yang menerima wewenang (agensi) yaitu manajer. Principal dan investor melakukan kontrak yang ditetapkan antara principal yang menggunakan agent untuk melaksanakan jasa yang menjadi kepentingan principal dalam hal terjadi pemisahan kepemilikan dan kontrol perusahaan. Agar hubungan kontraktual dapat berjalan lancar, maka principal akan mendelegasikan otoritas pembuatan keputusan kepada agent.

Tujuan dari sistem pemisahan ini adalah untuk menciptakan efisiensi dan efektivitas dengan memperkerjakan agen-agen profesional dalam mengelola perusahaan. Manajer sebagai pengelola perusahaan bertanggung jawab terhadap pemilik yang kemudian berimbas dengan pendanaan perusahaan baik dari investor atau kreditor. Manajer lebih banyak mengetahui informasi internal dan prospek perusahaan dimasa yang akan datang dibandingkan principal. Oleh karena itu sebagai pengelola, manajer berkewajiban untuk selalu transparan dalam melaksanakan kendali perusahaan di bawah principal.
Salah satu bentuk pertanggung jawabannya adalah dengan mengajukan laporan keuangan. Laporan keuangan yang diterbitkan oleh perusahaan merupakan salah satu sumber informasi mengenai posisi keuangan perusahaan, kinerja serta perubahan posisi keuangan perusahaan, yang sangat berguna untuk mendukung pengambilan keputusan yang tepat. Misalnya, jika laba yang diperoleh perusahaan nilainya tinggi dalam jangka waktu yang relatif lama, maka dapat dilihat bahwa perusahaan dapat menjalankan kegiatan operasinya dengan baik. Hal ini juga mengindikasikan bahwa dari nilai laba bersih yang diperoleh, perusahaan dapat melakukan pembagian deviden kepada setiap investornya. Oleh karena itu, kepercayaan yang diberikan kepada perusahaan akan semakin kuat dan perusahaan pun akan mendapatkan kredit dengan mudah dalam setiap kegiatan operasinya.

\section{Financial Distress}

Platt dan Platt (2002) mendefinisikan bahwa financial distress sebagai tahap penurunan kondisi keuangan yang terjadi sebelum terjadinya kebangkrutan ataupun likuidasi. Kondisi tersebut biasanya ditandai dengan penundaan pengiriman, penurunan kualitas produk, penundaan pembayara tagihan pada kreditor, kondisi tersebut apabila diketahui lebih dini maka perusahaan tidak akan sampai mengalami likuidasi atau kebangkrutan.

Definisi lain atas financial distress yang terkait dengan informasi pada laporan keuangan dalam Rismawaty (2012), Yaitu:

1. Almilia, Kristijadi (2003) financial distress adalah kondisi dimana perusahaan mengalami laba bersih operasi (net operation income) negatif selama beberapa tahun dan selama lebih dari satu tahun tidak melakukan pembayaran deviden, pemberhentian 
tenaga kerja atau menghilangkan pembayara dividen.

2. Luciana (2006) financial distress adalah kondisi dimana perusahaan mengalami delisted akibat laba bersih dan nilai buku ekuitas negatif berturut-turut serta perusahaan tersebut telah di merger.

\section{Indikator Financial Distress}

Ada beberapa indikator untuk mengetahui tanda-tanda kesulitan kesulitan keuangan yang dilihat dari pihak internal perusahaan yaitu:

a. Turunnya volume penjualan karena ketidakmampuan manajemen dalam menerapkan kebijakan dan strategi.

b. Turunnya kemampuan perusahaan dalam mencetak keuntungan.

c. Ketergantungan terhadap utang sangat besar.

Sebaliknya, beberapa indikator untuk mengetahui tanda-tanda kesulitan keuangan yang dilihat dari pihak eksternal yaitu:

a. Penurunan jumlah deviden yang dibagikan kepada pemegang saham selama beberapa periode berturutturut.

b. Penurunan laba secara terus-menerus dan perusahaan mengalami kerugian.

c. Ditutup atau dijualnya satu atau lebih unit usaha.

d. Pemecatan pegawai secara besarbesaran.

e. Harga dipasar mulai menurun terusmenerus.

Dampak financial distress tidak hanya memperburuk kondisi keuangan perusahaan tersebut, tetapi juga menimbulkan dampak lain seperti buruknya penilaian terhadap kinerja manajemen perusahaan, banyaknya pegawai/ karyawan penting yang keluar karena akan terjadi kemungkinan penurunan upah/ gaji, pemasok menolak untuk memberikan kredit dan kreditor tidak mau memberikan pinjaman.

\section{Analisis Rasio Keuangan}

Analisis rasio merupakan suatu teknik analisis yang menggambarkan hubungan antara satu pos dengan pospos lainnya yang terdapat dalam laporan keuangan. Analisis rasio menjelaskan dan memberikan gambaran dan posisi keuangan suatu perusahaan. Analisis rasio menurut Munawir (2004) adalah "suatu metode analisis untuk mengetahui hubungan dari pos-pos tertentu dalam neraca atau laporan laba rugi secara individu atau kombinasi dari kedua laporan tersebut".

\section{Jenis Rasio Keuangan}

Adapun rasio keuangan yang digunakan menurut Harahap (2008) adalah:

1. Rasio Likuiditas

2. Rasio Solvabilitas

3. Rasio Profitabilitas/ Rentabilitas

4. Rasio Leverage

5. Rasio Aktivitas

6. Rasio Pertumbuhan

7. Market Based (Penilaian Pasar), dan

8. Rasio Produktivitas

\section{Leverage}

Rasio ini mengukur kemampuan perusahaan memenuhi kewajibankewajiban jangka panjangnya (Hanafi, 2014). Rasio leverage juga menunjukkan resiko yang dihadapi perusahaan. Semakin besar resiko yang dihadapi perusahaan maka ketidakpastian untuk menghasilkan laba di masa depan juga akan semakin meningkat. Rasio leverage menunjukkan perlunya perusahaan memikirkan untuk menyediakan pendanaan hutang-hutang perusahaan yang sedang ditanggung. Pihak pemberi pinjaman perusahaan akan sangat memperhitungkan dan mengevaluasi rasio leverage perusahaan, karena pemberi pinjaman senantiasa menginginkan dana yang ia pinjamkan akan kembali lagi beserta bunga yang ia tanggungkan kepada perusahaan. 
Dalam penelitian ini rasio yang dipakai dalam mengukur leverage adalah Total liabilities to Debt to Total Assets (Rasio total utang terhadap total aktiva).

Rasio total utang terhadap total aktiva $=\frac{\text { Total liabilities }}{\text { Total Assets }}$

\section{Operating Capacity}

Operating capacity disebut juga dengan rasio efisiensi, rasio ini dihitung dengan total asset turnover yaitu dengan membandingkan total penjualan dengan total aset yang dimiliki oleh perusahaan. Rasio ini menunjukkan perputaran total aktiva diukur dari volume penjualan dengan kata lain seberapa jauh kemampuan semua aktiva menciptakan penjualan (Harahap, 2008). Dalam penelitian ini rasio yang dipakai untuk mengukur operating capacity adalah Total Assets Turn Over (Perputaran total aktiva).

\section{Perputaran total aktiva $=$ penjualan bersih Total Aktiva}

\section{Profit Margin}

Profit Margin merupakan salah satu rasio profiitabilitas. Profit margin menghitung sejauh mana kemampuan perusahaan menghasilkan laba bersih pada tingkat penjualan tertentu (Mamduh, 2014). Rasio ini bisa di interprestasikan sebagai kemampuan perusahaan menekan biaya-biaya (ukuran efisiensi) diperusahaan pada periode tertentu.

Profit margin yang diperoleh sedikit atau bahkan mengalami rugi maka pihak investor tidak akan mendapatkan dividen dan para investor menganggap bahwa perusahaan tidak mampu memperoleh laba pada operasi perusahaan. Rasio Profit margin bisa dihitung sebagai berikut:

$$
\text { Profit Margin }=\frac{\text { Laba bersih }}{\text { Penjualan }}
$$

\section{Financial Distress Dalam Padangan Islam}

Al-quran Surat Yunus (10) ayat 55:

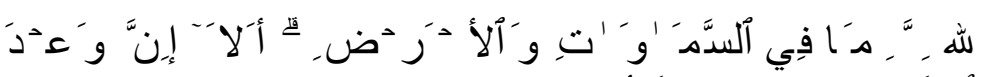

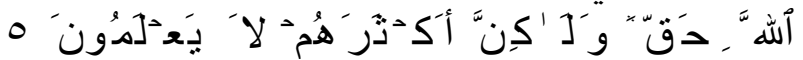

Artinya : Ingatlah, sesungguhnya kepunyaan Allah apa yang ada di langit dan di bumi. Ingatlah, sesungguhnya janji Allah itu benar, tetapi kebanyakan mereka tidak mengetahui(nya).

Penafsiran surat Yunus ayat 55 menurut tafsir Quraish Shihab: Hendaknya manusia mengetahui bahwa Allah SWT adalah Pemilik dan Pengendali semua yang ada di langit dan di bumi bahwa janji-Nya adalah benar hingga tidak sesuatu pun yang dapat melemahkan-Nya dan menghindar dari balasan-Nya. Tetapi mereka tidak tertipu oleh kehidupan dunia, dan mereka tidak mengetahuinya dengan sebenarnya.

\section{Kerangka Pemikiran}

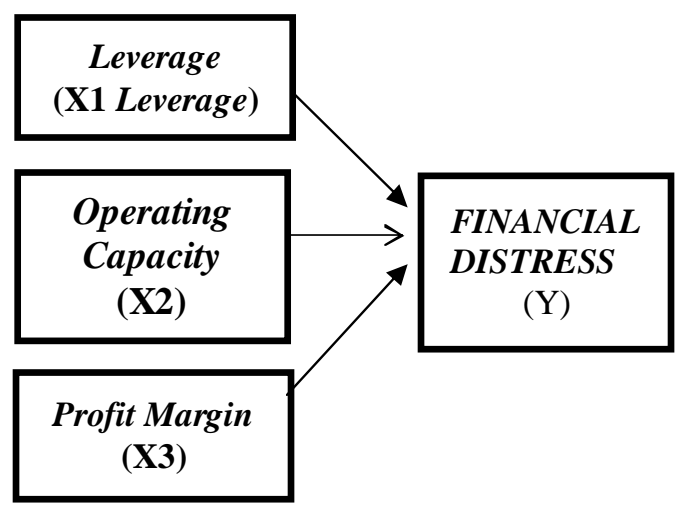

Sumber: data diolah 2018

\section{METODE PENELITIAN \\ Jenis dan sumber data}

Jenis penelitian yang digunakan dalam penelitian ini adalah penelitian kuantitatif dimana pengumpulan data berbentuk angka-angka dan hasil penelitian dianalisis menggunakan perhitungan statistik. Sumber data yang 
digunakan dalam penelitian ini adalah data sekunder, yakni data penelitian yang diperoleh secara tidak langsung melainkan melalui media perantara berupa laporan keuangan yang diterbitkan perusahaan-perusahaan yang terdaftar di Jakarta Islamic Index (JII) pada tahun 2012-2016. Data sekunder dalam penelitian ini diperoleh dari situs resmi Bursa Efek Indonesia yaitu http://www.idx.co.id.

\section{Metode pengumpulan data}

Teknik pengumpulan data dalam penelitian ini adalah melalui dokumen, yang dilakukan melalui observasi tidak langsung yaitu dengan mengumpulkan dokumen-dokumen laporan keuangan perusahaan. Pengambilan data melalui dokumen tertulis maupun elektronik dari lembaga/institusi. Dalam penelitian ini data yang diperoleh diambil dari laporan keuangan tahunan perusahaan yang terdaftar di Jakarta Islamic Index tahun 2012-2016.

\section{Populasi dan Sampel}

Pada bagian ini akan dijelaskan mengenai hal-hal yang berkaitan dengan populasi dan sampel penelitian, misalnya apa yang menjadi populasi, besar sampel yang diambil dan dasar penentuannya serta metode pengambilan sampel.

\section{Populasi}

Populasi adalah wilayah generalisasi yang terdiri atas: objek/ subjek yang mempunyai kualitas dan karakteristik tertentu yang ditetapkan oleh peneliti untuk dipelajari dan kemudian ditarik kesimpulannya (Sugiono, 2016).

Populasi dalam penelitian ini adalah perusahaan yang delisting dari Jakarta Islamic Index (JII) dan laporan keuangannya telah dipublikasikan pada tahun 2012-2016.

\section{Sampel}

Sampel merupakan bagian dari populasi. Sampel adalah bagian dari jumlah dan karakteristik yang dimiliki oleh populasi tersebut (Sugiono, 2016). Metode pengambilan sampel yang akan digunakan dalam penelitian ini adalah metode purposive sampling. Purposive sampling merupakan teknik sampling dimana berdasarkan pada kriteria-kriteria tertentu (Trianto, 2015). Kriteria yang dimaksud adalah :

a. Perusahaan yang delisting dari Jakarta Islamic Index (JII) selama periode 2012-2016.

b. Perusahaan yang mengalami laba negatif minimal dua tahun berturutturut/ perusahaan yang memiliki total Aset dari total liabilities.

c. Data yang dibutuhkan tersedia dengan lengkap dan menerbitkan laporan keuangan selama tahun penelitian.

d. Perusahaan yang konsisten menggunakan mata uang Rupiah atau Dolar Amerika.

Berdasarkan kriteria tersebut, didapatkan sampel sebanyak delapan perusahaan. Berikut daftar nama perusahaan-perusahaan tersebut:

Tabel 2. Daftar Perusahaan yang Menjadi Sampel Penelitian

\begin{tabular}{rcc}
\hline No. & Kode Perusahaan & Nama Perusahaan \\
\hline 1. & ANTM & Aneka Tambang (Persero) Tbk \\
\hline 2. & BTEL & Bakrie telecom Tbk \\
\hline 3. & ELTY & Bakrieland Development Tbk. \\
\hline 4. & ENRG & Energy Mega PersadaTbk. \\
\hline 5. & EXCL & XL AxiataTbk. \\
\hline 6. & INDY & Indika Energy Tbk. \\
\hline 7. & KRAS & Krakatau Steel (Persero) Tbk. \\
\hline 8. & TRAM & Trada Maritime Tbk. \\
\hline
\end{tabular}

Sumber: Data diolah 2018 


\section{TeknikAnalisis Data}

Analisis data dalam penelitian ini dibagi kedalam dua tahap. Data yang dikumpulkan dan diolah dalam penelitian ini kemudian dianalisis dengan menggunakan dua metode statistik, yaitu statistik deskriptif dan statistik induktif (uji hipotesis).

Menurut Ghozali (2013) dalam analisis pengujian model regresi logistik memperhatikan hal-hal sebagai berikut:

1. Menilai Model Regresi

Dalam menilai model regresi logistic dapat dilihat dari pengujian Hosmar and Lemeshow'sgoodnest of fit. Pengujian ini dilakukan untuk menilai model yang dihipotesiskan agar data empiris cocok atau sesuai dengan model. Jika nilai statistik Hosmar and Lemeshow'sgoodnest of fit test sama dengan atau kurang dari 0,05, maka hipotesis nol ditolak. Sedangkan jika nilainya lebih besar dari 0,05 , maka hipotesis nol tidak dapat ditolak, artinya model mampu memprediksi nilai observasinya atau cocok dengan data.

$\mathrm{H} 0=$ model yang dihipotesiskan fit dengan data

$\mathrm{Ha}=$ model yang dihipotesiskan tidak fit dengan data

2. Menilai keseluruhan model (Overal model fit)

Untuk menilai keseluruhan model, ditunjukkan dengan log likelihood value (nilai-2LL) yaitu dengan cara membandingkan antara nilai $2 \mathrm{LL}$ pada awal (block number $=0$ ) dimana model hanya memasukan konstanta dengan nilai - 2LL pada saat block number $=1$, dimana model memasukkan konstanta dan variabel bebas. Apabila nilai -2LL block number $=0>$ nilai -2LL block number $=1$, maka menunjukkan model regresi yang baik. Log likelihood pada regresi logistic mirip dengan pengertian "sum of square error" pada model regresi sehingga penurunan log likelihood menunjukkan model regresi semakin baik.

3. Menguji koefisien Regresi

Pengujian koefisien regresi dilakukan untuk menguji seberapa jauh semua variabel bebas yang dimasukkan dalam model mempunyai pengaruh terhadap variabel terikat. Untuk menentukan penerimaan atau penolakan HO dapat ditentukan dengan menggunakan wald statistic dan nilai probabilitas (sig) dengan cara wald statistic dibandingkan dengan chi square tabel. Sedangkan nilai probabilitas (sig) dibandingkan dengan tingkat signifikansi (a) 5\% dengan kriteria: H0 tidak dapat ditolak apabila wald statistic < chi square table dan nilai probabilitas signifikan $>$ tingkat signifikansi $(\alpha)$.

Adapun model regresi logistik yang digunakan adalah sebagai berikut:

$$
\mathrm{LN}=\frac{\mathrm{P}}{1-P}=\mathrm{b} 0+\mathrm{b} 1 \mathrm{LEV}+\mathrm{b} 2 \mathrm{OPC}+\mathrm{b} 3 \mathrm{PM}
$$

Dimana:

P : Probabilitas perusahaan yang mengalami financial distress

b0 : Konstanta

LEV : Leverage

OPC : Operating Capacity

PM : Profit margin

\section{HASIL DAN PEMBAHASAN Analisis Statistik Deskriptif}

Statistik deskriptif digunakan untuk menjelaskan kategori perusahaan financial distress dan non distress, untuk setiap setiap variabel independen dalam model penelitian. Analisis ini meliputi nilai minimum, maksimum, mean dan standar deviasi pada tahun 2012-2016 dengan menggunakan program SPSS 23.0 yang dapat dilihat pada tabel IV.1 berikut: 
2018, Jurnal Tabarru' : Is lamic Banking and Finance 1 (1) : 51 - 62

Tabel 3. Statistik Deskriptif Tahun 2012-2016

\begin{tabular}{|c|c|c|c|c|c|c|c|c|}
\hline \multirow{2}{*}{ Variabel } & \multicolumn{4}{|c|}{ Financial distress } & \multicolumn{4}{|c|}{ Nondistress } \\
\hline & Min & Max & Mean & St.deviasi & Min & Max & Mean & St. deviasi \\
\hline Leverage & .386 & .859 & .60687 & .121013 & .349 & 9.853 & 1.24772 & 2.122454 \\
\hline $\begin{array}{c}\text { Operating } \\
\text { capacity }\end{array}$ & .033 & .591 & .28958 & .144715 & .057 & .893 & .38777 & .220183 \\
\hline $\begin{array}{l}\text { Profit } \\
\text { margin }\end{array}$ & 2.775 & .293 & .32897 & .914011 & 21.515 & .286 & 1.83155 & 5.125925 \\
\hline
\end{tabular}

Sumber: Hasil olah data SPSS

Pengujian Uji Regresi Logistik

Pengujian hipotesis dilakukan dengan menggunakan metode analisis regresi logistik (logistic regression) karena memiliki satu variabel dependen (terikat) yang non metrik (nominal) serta memiliki variabel independen (bebas) lebih dari satu.

Menilai Model FIT
Pengujian hipotesis dilakukan untuk menguji pengaruh leverage, operating capacity, profit margin terhadap kondisi financial distress. Data yang digunakan untuk menganalisis variabel yaitu data laporan keuangan perusahaan tahun 2012-2016.

\section{Tabel 4. Uji Model Fit}

\begin{tabular}{lcc}
\hline & Uji Model Fit & Hasil \\
\hline -2 Log Likelihood & -2 LL Block Number O & 52.925 \\
& -2 LL Block Number 1 & 44.757 \\
\hline Hosmer and Lemeshow & Chi Square & 6.690 \\
Test & Sig & 0.570 \\
& Sumber: Hasil olah data SPSS &
\end{tabular}

\section{Cox \& Snell R Square}

Tabel 5. Uji Cox \& Snell R Square

\begin{tabular}{lc}
\hline \multicolumn{1}{c}{ Uji Cox \& Snell R Square } & Hasil \\
\hline Cox \& Snell R Square & 0.185 \\
\hline Nagelkerke R Square & 0.252 \\
\hline
\end{tabular}

Sumber: Hasil olah data SPSS

\section{Menguji Koefisien Regresi}

Analisis terakhir yaitu pengujian koefisien regresi untuk menguji seberapa jauh semua variabel bebas yang dimasukkan dalam model mempunyai pengaruh terhadap variabel terikat. Koefisien regresi dapat ditentukan dengan menggunakan Wald statistic dan nilai probabilitas (Sig.) seperti terlihat pada tabel 4. berikut: 
2018, Jurnal Tabarru' : Islamic Banking and Finance 1 (1) : 51 - 62

Tabel 6. Hasil Uji Koefisien Regresi Logistik Model Analisis Variabels in The Equation

\begin{tabular}{|c|c|c|c|c|c|c|c|c|}
\hline B & S.E. & Wald & Sig. & & $\operatorname{Exp}(B)$ & & & \\
\hline \multirow[t]{4}{*}{ Step $1^{\mathrm{a}}$} & \multicolumn{3}{|c|}{ Leverage } & -.556 & 2.084 & .074 & .786 & .568 \\
\hline & \multicolumn{3}{|c|}{ Operating capacity- 5.392} & & .9783 .967 & .046. & & \\
\hline & \multicolumn{3}{|c|}{ Profit Margin.694 .721} & & $26 \quad .3$ & 2.001 & & \\
\hline & \multicolumn{3}{|c|}{ Constant } & $2.21 \mathrm{C}$ & 1.518 & 2.137 & 144 & 9.197 \\
\hline
\end{tabular}

Dari model tersebut diatas dapat dinyatakan inerpretasi yang dilihat pada tampilan output variabel in the equation model analisis sebagai berikut:

$$
\begin{aligned}
& \operatorname{Ln} \frac{P}{1-P}=-2.219+-0.556 \mathrm{LEV}+-5.392 \\
& \text { OPC }-0.694 \mathrm{PM}
\end{aligned}
$$

Dari persamaan regresi tersebut dapat dilihat bahwa variabel bebas yang memiliki pengaruh positif ialah profit margin. Variabel bebas yang memiliki pengaruh positif artinya semakin tinggi nilai profit margin, maka probabilitas perusahaan akan mengalami financial distress juga semakin tinggi. Sedangkan variabel yang memiliki nilai negatif adalah leverage dan operating capacity yang artinya semakin tinggi nilai leverage dan operating capacity maka probabilitas perusahaan yang akan mengalami financial distress semakin rendah.

\section{KESIMPULAN}

Penelitian ini bertujuan untuk menyajikan bukti empiris mengenai faktor-faktor yang dapat digunakan untuk memprediksi kondisi financial distress pada perusahaan yang delisting dari Jakarta Islamic Index periode tahun 2012-2016 dengan menggunakan variabel-variabel yang diduga mempengaruhi financial distress perusahaan yaitu leverage, operating capacity, dan profit margin.

Selanjutnya data di uji dengan analisis regresi logistic pada program SPSS 23. Berdasarkan hasil yang diperoleh dari penelitian ini dapat diketahui bahwa kapasitas operasi (operating capacity) yang diproksikan dengan perputaran total asset (total asset turnover) menjadi salah satu alasan mengapa perusahaan dapat mengalami financial distress.

Karena kinerja yang kurang baik antara agen dan pemilik perusahaan, dapat mengakibatkan kondisi perusahaan yang buruk sehingga memicu terjadinya financial distress. Sehingga hasil penelitian ini memberikan bukti bahwa operating capacity dapat mempengaruhi kondisi financial distress. Sedangkan leverage dan profit margin belum mampu mempengaruhi kondisi financial distress. Perusahaan yang memiliki total liabilitas yang tinggi belum mampu mempengaruhi financial distress, karena sebagian besar perusahaan yang mengalami financial distress masih memiliki total asset yang tinggi sehingga perusahaan mampu membayar liabilitas dengan aset yang dimiliki. Sedangkan profit margin belum mampu mempengaruhi financial distress dikarenakan perusahaan masih memiliki ekuitas yang cukup untuk menanggung resiko dan juga memiliki total asset yang besar serta masih dapat mengendalikan beban-bebannya, maka profit margin tidak terlalu berpengaruh terhadap financial distress. 
DAFTAR PUSTAKA

Departemen Agama RI. 2008. AlQur'an dan terjemahnya. AlKafi. CV. Penerbit Diponegoro.

Andre, Orina dan Salma Taqwa. 2014. Pengaruh Profitabilitas, Likuiditas, dan Leverage Dalam Memprediksi Financial Distress. Jurnal WRA, Vol 2, No.1.

Ardiyanto, Feri Dwi dan Prasetiono. 2011. Prediksi Rasio Keuangan Terhadap Kondisi Financial Distress Perusahaan Manufaktur yang Terdaftar di BEI Periode 2005-2009. Jurnal Maksi Undip.

Cinanthya, I Gusti Agung Ayu P. dan Ni Ketut Lely Aryani Merkusiwati 2015. Pengaruh Corporate Governance, Financial Indicators, Dan Ukuran Perusahaan Pada Financial Distress. E-Jurnal Akuntansi Universitas Udayana 10.3: 897915.

Fahmi, Irham. 2014. Pengantar Manajemen Keuangan Teori dan Soal Jawab. Penerbit Alfabeta, Bandung.

Ghozali, Imam. 2013. Aplikasi Analisis Multivariate dengan Program SPSS 23. Badan Penerbit Universitas Diponegoro. Semarang.

Hadi, Selfi Anggraini Fauziah dan Andayani. 2014. Mekanisme Corporate Governance Dan Kinerja Keuangan Pada Perusahaan Yang Mengalami Financial Distress. Jurnal Ilmu \& Riset Akuntansi Vol. 3 No. 5

Hanafi, Mamduh M. dan Abdul Hakim. 2014. Analisis Laporan Keuangan, Edisi Keempat, Cetakan Ketiga. UPP AMP YKPN. Yogyakarta.

Hanifah, Okta Earning dan Agus Purwanto. 2013. Pengaruh Struktur Corporate Governance
Dan Financial Indicators

Terhadap Kondisi Financial Distress. Diponegoro Journal of Accounting Volume 2, Nomor 2.

Harahap, Sofyan Safri. 2008. Analisis Kritis atas Laporan Keuangan. PT. Raja Grafindo Persada. Jakarta

Huda, Nasution. 2008. Investasi Pada Pasar Modal Syariah, Edisi Revisi. Penerbit Kencana. Jakarta

Ikatan Akuntan Indonesia. 2009. Standar Akuntansi Keuangan per $1 \mathrm{Juli}$ 2009. Salemba Empat. Jakarta

Jensen, M. and Meckling, W., 1976 .Theory of the Firm: Managerial Behavior Agency Cost, and Ownership Structure., Journal of Finance Economics 3, pp. 305360.

Jiming dan Weiwei. 2011. An Empirical Study on the Corporate Financial Distress Prediction Based on Logistic Model Evidence from China's Manufacturing Industry. International Journal of Digital Content Technology Vol.5 No.6. Jumingan, 2008. Analisis laporan keuangan. Bumi Aksara. Jakarta.

Kasmir. 2009. Analisis Laporan Keuangan. Rajawali Pers. Jakarta.

Kusanti, Okta dan Andayani. 2015. Pengaruh Good Corporate Governance Dan Rasio Keuangan Terhadap Financial Distress pada perusahaan manufaktur yang terdaftar di Bursa Efek Indonesia tahun 2010-2013. Jurnal Ilmu \& Riset Akuntansi Vol. 4 No. 10

Mas'ud, Imam dan Reza Maymi Srengga. 2012. Analisis Rasio Keuangan Untuk memprediksi Kondisi Financial Distress Perusahaan manufaktur Yang Terdaftar Di Bursa Efek 
2018, Jurnal Tabarru' : Islamic Banking and Finance 1 (1) : 51 - 62

Indonesia. Jurnal Akuntansi Universitas Jember.

Novandri, Tio. 2014. Peranan Analisis Rasio Keuangan Dalam Memprediksi Kondisi Financial Distress Perusahaan Sektor Perdagangan. Jurnal Ilmu Manajemen Universitas Negeri Surabaya. Volume 2 Nomor 4.

Pasaribu, Rowland Bismark Fernando. 2008. Penggunaan Binary Logit Untuk Prediksi Financial Distress Emiten di BEI. Jurnal Ekonomi Bisnis \& Akuntansi Ventura, Vol. 11. No. 2.

Putri, Ni Wayan Krisnayanti Arwinda dan Ni Kt. Lely A. Merkusiwati. 2014. Pengaruh Mekanisme Corporate Governance, Likuiditas, Leverage, Dan Ukuran Perusahaan Pada Financial Distress. E-Jurnal Akuntansi Universitas Udayana.

Qashier Abbas and Abdul Rashid. 2011. Modeling Bankruptcy Prediction for Non-Financial Firms: The Case of Pakistan. International Islamic University (IIU), Islamabad, Pakista. MPRA Paper No. 28161.

Rahardjo. 2006. Keuangan dan Akuntansi untuk Manajer Non Keuangan. Graha Ilmu. Yogyakarta.

Rahardjo. 2008. Pengantar Akuntansi. Erlangga. Jakarta.

Sekaran, Uma. 2006. Metodologi Penelitian untuk Bisnis. Salemba Empat. Jakarta.

S. Munawir. 2009. Analisa Laporan Keuangan. Liberty Yogyakarta.

Widarjo, Wahyu dan Doddy Setiawan. 2009. Pengaruh Rasio Keuangan Terhadap Kondisi Financial Distress Perusahaan Otomotif. Jurnal bisnis dan akuntansi vol.11 No.2.
Sindonews.com, PT. aneka tambangantam, https: ekbis. sindonews.com diakses pada 5 oktober 2017, 17:26.

Sindonews.com, "Laba bersih ITMG merosot" https: ekbis.sindonews.com. diakses pada 25 agustus 2017, 14:03.

Sindonews.com, "Krakatau Steel alami laba negatif". https: ekbis.sindonews.com. diakses pada 5 oktober 2017, 17:29.

Sindonews.com, "Rugi bersih, XL axiata tak bayar deviden" https: ekbis. sindonews.com. diakses pada 5 oktober 2017, 17:35.

Wikipedia.org."Jakarta Islamic Index". https : id. Wikipedia.org diakses pada 25 agustus 2017,14:19. 